International Journal of Agriculture, Environment and Bioresearch

Vol. 4, No. 04; 2019

ISSN: $2456-8643$

\title{
METHODOLOGY TO MEASURE LIVELIHOOD SECURITY OF REHABILITANT FARMERS
}

\author{
Jagadajyoti Binkadakatti $^{1}$ and J.G.Angadi ${ }^{2}$ \\ ${ }^{1}$ Scientist-C, Research Extension Centre, Central Silk Board, Palampur (Himachal Pradesh) \\ ${ }^{2}$ Professor, Department of Agricultural Extension Education, University of Agricultural Sciences, Dharwad, \\ Karnataka
}

http://doi.org/10.35410/IJAEB.2019.4420

\begin{abstract}
Livelihood Security refers to the secure ownership of or access to resources and income generating activities including assets to meet basic needs. These basic needs include adequate health facilities, shelter, level of income, basic education and community participation in social activities. If any of these basic needs is not met, those households become insecure. This developed methodology helps to analyze the livelihood security of the rehabilitant farmers of Upper Krishna Project Area (UKP). Livelihood Security index (LSI) and Sub-indexes were developed with the help of weightage given by the different disciplined/professional judges. Livelihood security of the rehabilitant farmers was measured by using LSI. Livelihood Security of the rehabilitant farmers was found to be 54.66 percent. Among the components of Livelihood Security, natural capital was observed low (48.77\%). Human capital (63.59\%) and social capital (55.24\%) performed moderately among all the capitals. The developed methodology enable the researchers, academicians and policy makers to assess the Livelihood Security of any Project Displaced farm Families (PDF) due to displacement by corporate companies (Steel, Mining, Nuclear power etc) National Highway, Special Economic Zone (SEZ) and also due to natural calamities like drought, flood, earth quick, etc., if it is proved to be reliable in new conditions.
\end{abstract}

Keywords: Livelihood security index (LSI), Rehabilitant farmers, Livelihood capitals.

\section{INTRODUCTION}

The Upper Krishna Project (UKP) is one of the biggest projects in India. It was started as a multipurpose irrigation project in the drought prone northern parts of Karnataka across the river Krishna covering Bagalkot, Bijapur, Belgaum, Gulbarga and Raichur districts. The UKP consists of two dams across the river. The upper dam is located at Alamatti village, of Karnataka state which has hill range to provide the ideal site for bulk storage of water (i.e. storage cum distributor dam) and the lower dam serves mainly as a diversion/ distribution dam which is located at Narayanpur village. Totally Narayanpura and Almatti dams together displaced 176 villages involving 94,043 families of 3,50,880 people.

The concept of Sustainable Livelihood Security (SLS) is defined as 'livelihood options which are ecologically secure, economically efficient and socially equitable' (Swaminathan, 1991). Tanvir et al. (2007) conducted a study on livelihood assets of forest dependent communities in northern Pakistan and used the Sustainable Livelihoods Framework (SLF) developed by the British 
Department for International Development (DFID) as an analytical framework to investigate the impact of institutional changes on (access to) livelihood assets viz., natural, physical, financial, human and social. Lindenberg (2002) in his study on measuring household livelihood security at the family and community level in the developing world, household livelihood security is defined as a family's or community's ability to maintain and improve its income, assets and social well-being from year to year. According to Nesar et al. (2010) the sustainable Livelihood framework shows how, in differing contexts, sustainable livelihoods are achieved through access to a range of livelihood assets viz., natural, physical, financial, human and social which are combined in the pursuit of different livelihood strategies.

Uday Kumara and Shrestha (2011) in their study on assessing livelihood for improvement in Sri Lanka, they considered five livelihood assets (human, natural, financial, physical and social) as suggested in the framework. Further, each asset was represented by two to three selected indices, each of which was based on a number of individual decision variables ranging from one to four. Livelihood index was computed as five capital assets namely human, natural, financial, physical and social assets. Each of which was divided into sub-indices for each asset class using factor analysis, while decision variables were directly used in multiple regression and optimisation procedures, as these are important in policy interventions.

In the present study, Livelihood Security refers to the secure ownership of or access to resources and income generating activities including assets to meet basic needs. These basic needs include adequate health facilities, shelter, level of income, basic education and community participation in social activities. If any of these basic needs is not met, those households become insecure. Therefore, there is a need to develop the Livelihood Index (LI) to measure the Livelihood Security of rehabilitant farmers of UKP (Upper Krishna Project) area.

\section{MATERIALS AND METHODS:}

Livelihood Index (LI) was computed as five capital assets namely human, natural, financial, physical and social asset. To measure the livelihood security there is a need to develop the Livelihood index of these five capitals. Further, to measure each capital index there is a need to develop sub-component index also.

\section{Development of methodology to study Livelihood index}

The main livelihood components i.e. Five capital assets namely human, natural, financial, physical and social asset were selected and sub-components for each capital was identified with the help of Expert judges rating. Further, Weightage was given to each sub-component of livelihood capitals with the help of judges rating and finally Livelihood security index was developed.

\section{Development and measurement of Livelihood capitals}

\section{NATURAL CAPITAL}

Natural capital is operationalised as the extent of natural resources, viz., land, soil, water, topography, vegetation and livestock composition possessed by the rehabilitant farmers at the 
time of investigation. Further, each sub-component of natural capital is measured by considering following indicators as given below.

\begin{tabular}{|l|l|l|}
\hline Sl. No. & Sub components & Indicators \\
\hline \multirow{4}{*}{ I. 1 } & Land resource & Land resource index (LRI) \\
\cline { 2 - 3 } & A. Type of land & Land type index (LTI) \\
\cline { 2 - 3 } & B. Type of Soil & Soil type index (STI) \\
\cline { 2 - 3 } & C. Land Topography & Topography index (TI) \\
\hline \multirow{2}{*}{ I. 2 } & Source of Irrigation & Irrigation source index (ISI) \\
& Farming System & Farming system index (FSI) \\
\cline { 2 - 3 } & A. Crop Enterprise & Crop enterprise index (CEI) \\
\cline { 2 - 3 } & B. Cropping System & Cropping system index (CSI) \\
\cline { 2 - 3 } & C. Integrated farming system & Integrated farming system index (IFSI) \\
\hline I. 4 & Vegetation & Vegetation index (VI) \\
\hline I. 5 & Livestock composition & Livestock composition index (LCI) \\
\hline & Natural capital & Natural capital index (NCI) \\
\hline
\end{tabular}

\section{I.1. Land resources}

\section{I.1. A) Type of land}

The type of land was classified as uncultivable, rainfed and irrigated. Further, weightages were assigned based on the judges rating as indicated below.

\begin{tabular}{|l|l|l|}
\hline Sl. No. & Type of land (Maximum 10 acre) & Weightages \\
\hline 1 & Un-cultivable & 1 \\
\hline 2 & Rainfed & 2 \\
\hline 3 & Irrigated & 3 \\
\hline
\end{tabular}

Maximum possible score for type of land is $\mathbf{3 0}$

[The maximum possible score of 30 for type of land was obtained by multiplying the highest type of land weightage with maximum land holding of 10 acre (i.e. 3 x $10=30$ ). Because, farmer may possess rainfed, irrigated and un-cultivable land or either of one for their farming activities]

\section{I.1. B) Type of soil}

The types of soil namely black, red, sandy were considered under both rainfed and irrigated land. Weightages were assigned for each item based on the judges rating as follows.

\begin{tabular}{|l|l|l|}
\hline SI. No. & Type of soil (Maximum 10 acre) & Weightages \\
\hline 1 & Under Rainfed & \\
\hline & Black soil & 3 \\
\hline & Red soil & 2 \\
\hline & Sandy soil & 1 \\
\hline
\end{tabular}




\begin{tabular}{|l|l|l|}
\hline 2 & Under irrigated & \\
\hline & Black soil & 2 \\
\hline & Red soil & 3 \\
\hline & Sandy soil & 1 \\
\hline
\end{tabular}

Maximum possible score for type of soil is $\mathbf{3 0}$

[The maximum possible score of 30 for type of soil was obtained by multiplying the highest type of soil weightage with maximum acre of land holding (i.e. $3 \times 10=30$ ). Because, farmers may possess black, red and sandy soil or either of one under irrigated or rainfed condition for their livelihood activities]

\section{I.1. C) Land topography}

It refers to the extent of slope of land in per cent possessed by the rehabilitant farmers. Weightages were assigned for different range of slope of land based on the judges rating. It is indicated as below.

\begin{tabular}{|l|l|l|}
\hline Sl. No. & Land topography (Maximum 10 acre) & Weightages \\
\hline 1 & Lower (<3\% slope) & 3 \\
\hline 2 & Medium (3-5\%) & 2 \\
\hline 3 & Higher $(>5 \%)$ & 1 \\
\hline
\end{tabular}

Maximum possible score for land topography is $\mathbf{3 0}$

[The maximum possible score of 30 for land topography was obtained by multiplying the highest item weightage with maximum acre of land holding (i.e. $3 \times 10=30)$ ]

The maximum possible score of land resource includes

\begin{tabular}{|l|l|c|l|}
\hline & Land resources & & Maximum score \\
\hline A. & Type of land & $=$ & 30 \\
\hline B. & Type of Soil & $=$ & 30 \\
\hline C. & Land Topography & $=$ & 30 \\
\hline & Total & $=$ & $\mathbf{9 0}$ \\
\hline
\end{tabular}

Score related to type of land + type of soil + land topography

Land Resource Index (LRI) = $\times 100$

\section{2. Source of irrigation}

Maximum possible score

It refers to the type and extent of irrigation sources like canal, bore well etc available for the rehabilitant farmers. Based on the extent of possession of land under irrigation by the rehabilitant farmers, maximum of 6 acres of irrigated land was considered for quantification. The weightages of 1, 2 and 3 were assigned for open well, bore well and canal, respectively based on the judges rating. It is indicated as below. 


\begin{tabular}{|l|l|l|}
\hline Sl. No. & Source of irrigation (Maximum 6 acre) & Weightages \\
\hline 1 & Open well & 1 \\
\hline 2 & Bore well & 2 \\
\hline 3 & Canal & 3 \\
\hline
\end{tabular}

Maximum possible score for source of irrigation is $\mathbf{1 8}$

[The maximum possible score of 18 for source of irrigation was obtained by multiplying the highest type of irrigation source weightage with maximum 6 acres of irrigated land (i.e. $3 \times 6=$ 18). Because, farmers had source of irrigation from open well, Bore well and canal or either of one.]

\section{3. Farming systems}

\section{3. A) Crop enterprise}

It refers to the type and extent of crop cultivation like agriculture crops (i.e. cereals, pulses, oilseeds, commercial crops etc) and horticulture crops (i.e. vegetables, fruits etc) by the rehabilitant farmers at the time of investigation. Weightages were assigned based on the judges rating as follows.

\begin{tabular}{|l|l|l|}
\hline SI. No. & Type of crop enterprise (Maximum 10 acre) & Weightages \\
\hline $\mathbf{1}$ & Agriculture crops (Max-8 acre) & \\
\hline & Cereals/millets & 1 \\
\hline & Pulses & 2 \\
\hline & Oilseeds & 3 \\
\hline & Commercial crops & 5 \\
\hline 2 & Horticulture crops (Max-2 acre) & \\
\hline & Fruit crops & 1 \\
\hline & Vegetables & 2 \\
\hline
\end{tabular}

Maximum possible score for crop enterprise is $\mathbf{4 4}$

[The maximum possible score of 44 for crop enterprise was obtained by multiplying the highest type of crop weightage with maximum 10 acres of land holding [i.e. $(5 \times 8=40)+(2 \times 2=4)$ $=44]$. Because, farmers may grow agriculture and horticulture crops or either of one for the improvement of their livelihoods]

\section{3. B) Cropping system}

It refers to the type and extent of cropping pattern followed by the rehabilitant farmers. Weightages were assigned based on the judges rating as follows.

\begin{tabular}{|l|l|l|}
\hline Sl. No. & Type of cropping system (Maximum 10 acre) & Weightages \\
\hline 1 & Mono-cropping & 1 \\
\hline 2 & Intercropping & 2 \\
\hline 3 & Draw down cultivation & 2 \\
\hline 4 & Double/sequential & 3 \\
\hline
\end{tabular}

Maximum possible score for cropping system is $\mathbf{3 0}$ 
[The maximum possible score of 30 for cropping system was obtained by multiplying the highest cropping system weightage with maximum 10 acres of land holding (i.e. $3 \times 10=30$ ). Because, farmer may practice mono/double/multiple cropping system and draw down cultivation or either of one]

\section{3. C) Integrated farming system}

It refers as an appropriate combination of different farm enterprises viz. crop enterprise, cropping system, livestock, poultry, Goat/sheep rearing and the means available to the rehabilitant farmers to raise them for increasing incomes and profitability. Following three types of farming systems with weightages were considered based on the judges rating for quantification of the farming system. It is as indicated below.

\begin{tabular}{|l|l|l|}
\hline Sl. No. & Type of Integrated farming system (Maximum 10 acre) & Weightages \\
\hline 1 & Crop only (Max-8 acre) & 1 \\
\hline 2 & Crop + dairy (Max-1 acre) & 3 \\
\hline 3 & $\begin{array}{l}\text { Crop + Horticulture + Dairy + Poultry + Goat/Sheep } \\
\text { (Max-1 acre) }\end{array}$ & 4 \\
\hline
\end{tabular}

Maximum possible score for farming system is $\mathbf{1 5}$

[The maximum possible score of 15 for farming system was obtained by multiplying the highest type of farming system weightage with maximum 10 acres of land holding [i.e. $(1 \times 8=8)+(1 \mathrm{x}$ $3=3)+(1 \times 4=4)=15]$

The maximum possible score of farming system includes

\begin{tabular}{|l|l|l|l|}
\hline & Types & & Maximum score \\
\hline A. & Crop enterprise & $=$ & 44 \\
\hline B. & Cropping system & $=$ & 30 \\
\hline C. & Integrated farming system & $=$ & 15 \\
\hline & Total & $=$ & $\mathbf{8 9}$ \\
\hline
\end{tabular}

Score related to crop enterprise + cropping system + integrated farming system

Farming System Index (FSI) =

Maximum possible score

\section{4. Vegetation}

It refers to the extent of vegetation cover including grass and fodder established by the rehabilitant farmers at the time of investigation. Based on the extent of possession of vegetation by the rehabilitant farmers, maximum 2 acres of land (i.e. 1 acre for fodder crops and 1 acre for grass) was considered for quantification of the vegetation. Weightages were assigned based on the judges rating as indicated below. 


\begin{tabular}{|l|l|l|}
\hline Sl. No. & Type of vegetation (Maximum 2 acre) & Weightages \\
\hline 1 & Fodder crops (Max-1 acre) & 1 \\
\hline 2 & Grass (Max-1 acre) & 2 \\
\hline
\end{tabular}

Maximum possible score for vegetation is $\mathbf{0 3}$

[The maximum possible score of 6 for vegetation was obtained by multiplying the highest type of vegetation weightage with maximum land holding [i.e. $(1 \times 1=1)+(1 \times 2=2)=03)$. Because, farmers may grow grass and fodder crops or either of one as feed for livestock's]

\section{5. Livestock composition}

Livestock composition includes possession of buffaloes/cows, bullocks, goat/sheep and poultry by the rehabilitant farmers at the time of survey. Weightages for different types and number of livestock were assigned based on judges rating as follows.

\begin{tabular}{|l|l|l|}
\hline Sl. No & Type of Livestock component & Weightages \\
\hline $\mathbf{1}$ & Buffaloes/cows & \\
\hline & Up to 2 & 2 \\
\hline & $3-4$ & 3 \\
\hline & $5-6$ & 3 \\
\hline & $>6$ & 4 \\
\hline $\mathbf{2}$ & Bullocks & \\
\hline & Up to 2 & 2 \\
\hline & $3-4$ & 4 \\
\hline $\mathbf{3}$ & Goats/ Sheep & \\
\hline & Up to 3 & 1 \\
\hline & $3-6$ & 2 \\
\hline & $>6$ & 3 \\
\hline $\mathbf{4}$ & Poultry & \\
\hline & Up to 5 & 1 \\
\hline & $5-10$ & 2 \\
\hline & $>10$ & 3 \\
\hline
\end{tabular}

Maximum possible score for livestock composition is $\mathbf{1 4}$

[The maximum possible score of 14 for livestock composition was obtained by summing all the livestock composition maximum weightages (i.e. $4+4+3+3=14$ )]

The maximum possible score of natural capital includes

\begin{tabular}{|l|l|l|l|}
\hline & Sub components & & Maximum score \\
\hline 1. & Land resource & $=$ & 90 \\
\hline 2. & Source of Irrigation & $=$ & 18 \\
\hline 3. & Farming System & $=$ & 89 \\
\hline 4. & Vegetation & $=$ & 03 \\
\hline 5. & Livestock composition & $=$ & 14 \\
\hline & Total & $=$ & $\mathbf{2 1 4}$ \\
\hline
\end{tabular}

Therefore, 


\section{Maximum possible score for natural capital is 214}

The natural capital index is the ratio of score related to land resource, source of irrigation, farming system, vegetation and livestock composition to the maximum possible score of natural capital multiplied with hundred. The formula is as follows.

Score related to land resource + source of irrigation + farming

$$
\text { system + vegetation + livestock composition }
$$

Natural Capital Index $(\mathrm{NCI})=$

Maximum possible score of natural capital

\section{PHYSICAL CAPITAL}

Physical capital is operationalised as the basic infrastructure facilities like means of transport, type of house, source of energy for cooking, household material, source of lighting, farm implements and farm machineries possessed by the rehabilitant farmers. Each sub component of physical capital is measured by considering following sub-components and indicators as given below.

\begin{tabular}{|l|l|l|}
\hline Sl.No. & Sub-components & Indicators \\
\hline II.1 & Means of transport & Means of transport index (MTI) \\
\hline II.2 & Type of house & House type index (HTI) \\
\hline \multirow{4}{*}{ II.3 } & Household facilities & Household facility index (HFI) \\
\cline { 2 - 3 } & A) Source of energy for cooking & Source of energy index (SEI) \\
\cline { 2 - 3 } & B) Household material possession & Household material index (HMI) \\
\cline { 2 - 3 } & C) Source of lighting & Source of lighting index (SLI) \\
\hline \multirow{3}{*}{ II.4 } & Farm implements and machineries & $\begin{array}{l}\text { Farm implements and machineries } \\
\text { index (FIMI) }\end{array}$ \\
\cline { 2 - 3 } & A) Farm implements & Farm implements index (FII) \\
\cline { 2 - 3 } & B) Farm machinery & Farm machinery index (FMI) \\
\hline & Physical capital & Physical capital index (PCI) \\
\hline
\end{tabular}

\section{II .1. Means of transport}

Means of transport is operationalised as the possession/affordability of the rehabilitant farmers for using the transport facilities for various purposes. Weightages were assigned for means of transport based on the judges rating for quantification of means of transport. It is as indicated below.

\begin{tabular}{|l|l|l|}
\hline Sl. No. & Type of transport means & Weightages \\
\hline 1 & Bullock cart & 1 \\
\hline 2 & Tractor & 3 \\
\hline
\end{tabular}

Maximum possible score for means of transport is 4

[The maximum possible score of 4 for means of transport was obtained by combining bullock cart and tractor weightages (i.e. $1+3=4$ ). Because, farmers use Bullock cart and tractor or either of one for transportation of agricultural products]

Score related to types of means of transport 
Means of Transport Index $(\mathrm{MTI})=$ $\times 100$

\section{II.2 Type of house}

Maximum possible score

It refers to the house type where the rehabilitant farmers are living at the time of investigation. Following three types of houses with weightages were considered for quantification of house type as indicated below.

\begin{tabular}{|l|l|l|}
\hline Sl. No. & Type of house & Weightages \\
\hline 1 & Kaccha (Gudisalu/tagadu) & 1 \\
\hline 2 & Pucca (Madige mane/tiles) & 2 \\
\hline 3 & Concrete building & 3 \\
\hline
\end{tabular}

Maximum possible score for types of house is $\mathbf{3}$

[The maximum possible score of 3 for type of house was obtained by considering highest weightages among the type of house.]

Score related to types of house

\section{II.3 Household facilities}

House Type Index $($ HTI $)=---------------------------~ \times 100$

\section{II.3 A) Source of energy for cooking}

It refers to the source of energy available for the cooking purpose for the rehabilitant farmers at the time of investigation. Weightage of 1,2 , and 3 were given for sources of energy like kerosene, fire wood and LPG respectively based on the judges ratings. It is as indicated below.

\begin{tabular}{|l|l|l|}
\hline Sl. No. & Source of energy for cooking & Weightages \\
\hline 1 & Kerosene & 1 \\
\hline 2 & Fire wood & 2 \\
\hline 3 & LP Gas & 3 \\
\hline
\end{tabular}

Maximum possible score for source of energy for cooking is $\mathbf{6}$

[The maximum possible score of 6 for source of energy was obtained by summing of all items weightages (i.e. $1+2+3=6$ )]

Source of Energy Index $(\mathrm{SEI})=\frac{\mathrm{Score} \text { related to kerosene }+ \text { fire wood }+ \text { LPG }}{\text { Maximum possible score }}$
Ma

\section{3. B) Household material possession}

It refers to the different household materials possessed by the rehabilitant farmers at the time of investigation. Following five type of house materials with weightages were considered for quantification of household's materials possession. It is indicated as below.

\begin{tabular}{|l|l|l|}
\hline Sl. No. & Types of household material possession & Weightages \\
\hline 1 & Radio/FM & 1 \\
\hline
\end{tabular}




\begin{tabular}{|l|l|l|}
\hline 2 & Television & 2 \\
\hline 3 & Fan & 1 \\
\hline 4 & Cot & 1 \\
\hline 5 & Mobile/phone & 2 \\
\hline
\end{tabular}

Maximum possible score for household material possession is 7

[The maximum possible score of 7 for household material possession was obtained by combining all items weightages (i.e. $1+2+1+1+2=7$ ). Because, farmers may have all household materials or either of one]

Score related to types of households material

Households Material Index (HMI) = $\times 100$

\section{II.3 C) Source of lighting}

Maximum possible score

It refers to the different type of lighting sources owned by the rehabilitant farmers at the time of investigation. Following two sources of lighting with weightages were considered for quantification of source of lighting. It is as indicated below.

\begin{tabular}{|l|l|l|}
\hline Sl. No. & Source of lighting & Weightages \\
\hline 1 & Kerosene/candle & 1 \\
\hline 2 & Electricity & 2 \\
\hline
\end{tabular}

Maximum possible score for source of lighting is $\mathbf{3}$

[The maximum possible score of 3 for source of lighting was obtained by summing all items weightage (i.e. $1+2=3$ ). Because, farmers may have kerosene/ candle and electricity or either one as source of lighting for house]

Score related to types of source of lighting

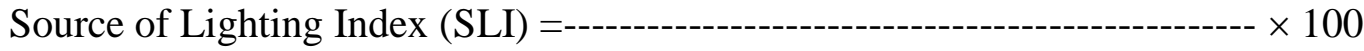

Maximum possible score

The maximum possible score of Household facilities includes

\begin{tabular}{|c|l|c|l|}
\hline & Types of household facilities & & Maximum score \\
\hline 1. & Source of energy for cooking & $=$ & 6 \\
\hline 2. & Household material possession & $=$ & 7 \\
\hline 3. & Source of lighting & $=$ & 3 \\
\hline & Total & $=$ & $\mathbf{1 6}$ \\
\hline
\end{tabular}

Score related to source of energy + household material possession + source of lighting

Household facilities index $(\mathrm{HFI})=$ -

\section{4. Farm implements and machineries \\ II. 4. A) Farm implements}


It refers to the type and number of farm implements (i.e. wooden plough, iron plough, harrow, seed drill, hand sprayer, bullock cart etc) used by the rehabilitant farmers at the time of investigation to produce the agriculture products. Following six types of implements with weightages were considered for quantification of farm implements. It is indicated as below.

\begin{tabular}{|l|l|l|}
\hline Sl. No. & Type of farm implements & Weightages \\
\hline 1 & Wooden Plough & 2 \\
\hline 2 & Iron plough & 2 \\
\hline 3 & Harrow & 2 \\
\hline 4 & Seed drill & 2 \\
\hline 5 & Bullock cart & 2 \\
\hline 6 & Hand sprayer & 1 \\
\hline
\end{tabular}

Maximum possible score for farm implements is $\mathbf{1 1}$

[The maximum possible score of 11 for farm implements was obtained by combining all items weightages (i.e. $2+2+2+2+2+1=11$ )

Score related to types of farm implements

Farm Implements Index (FII)

Maximum possible score

\section{II.4. B) Farm machineries}

refers to the mechanical units like tractor including tractor drawn implements and pump sets used by the rehabilitant farmers for the purpose of agriculture activities. Following two farm machineries with weightages were considered for quantification of farm machineries. It is as indicated below.

\begin{tabular}{|l|l|l|}
\hline Sl. No. & Farm machineries & Weightages \\
\hline 1 & Pump set & 2 \\
\hline 2 & Tractor/tractor drawn implements & 3 \\
\hline
\end{tabular}

Maximum possible score for farm machineries is $\mathbf{5}$

[The maximum possible score of 5 for farm machineries was obtained by combining both tractor and pump set weightages (i.e. $2+3=5)]$

Score related to types of farm machineries

Farm Machineries Index (FMI) = ------------------------------------------------- × 100

Maximum possible score

The maximum possible score of farm implements and machineries includes

\begin{tabular}{|l|l|l|l|}
\hline & Types & & Maximum score \\
\hline 1. & Farm implements & $=$ & 11 \\
\hline 2. & Farm machineries & $=$ & 5 \\
\hline & Total & $=$ & $\mathbf{1 6}$ \\
\hline
\end{tabular}

Score related to types of farm

implements and machineries 
Farm implements and machineries Index $($ FIMI $)=$ $\times 100$

Maximum possible score

The maximum possible score of physical capital includes

Therefore,

\begin{tabular}{|c|l|c|l|}
\hline & Sub components & & Maximum score \\
\hline 1. & Means of transport & $=$ & 3 \\
\hline 2. & House type & $=$ & 4 \\
\hline 3. & Household facilities & 16 \\
\hline 4. & Farm implements and machineries & $=$ & 16 \\
\hline & Total & $=$ & $\mathbf{3 9}$ \\
\hline
\end{tabular}

Maximum possible score for physical capital is 39

The physical capital index is the ratio of score of means of transport + type of house + household facilities + farm implements and machineries to the maximum possible score of physical capital multiplied with hundred. The formula is as follows.

Score related to means of transport + type of house +

household facilities + farm implements and machineries

Physical Capital Index $(\mathrm{PCI})=$

Maximum possible score of physical capital

\section{FINANCIAL CAPITAL}

Financial capital is operationalised as the capital bases or financial resources like cash/annual income, expenditure, credit/loans and savings accessed by the rehabilitant farmers. Each sub components of financial capital is measured by considering following sub-components and indicators as given below.

\begin{tabular}{|l|l|l|}
\hline SI. No. & Sub-components & Indicators \\
\hline III.1 & Annual income & Annual income index (AII) \\
\hline III.2 & Annual expenditure & Annual expenditure index (AEI) \\
\hline III.3 & Loan/credit & Loan index (LI) \\
\hline III.4 & Repayment & Repayment index (RI) \\
\hline III.5 & Savings & Savings index (SI) \\
\hline & Financial capital & Financial capital index (FCI) \\
\hline
\end{tabular}

\section{1. Annual income}

It refers to the cumulative income earned by the rehabilitant farmers from main and subsidiary sources in a year at the time of investigation. Following weightages were assigned based on the annual income classification of the Ministry of Rural Development, Government of India. It is as indicated below. 


\begin{tabular}{|l|l|l|}
\hline Sl. No. & Category & Weightages \\
\hline 1 & Lower income groups (<Rs. 60000) & 1 \\
\hline 2 & Medium income groups (Rs. 60000 to 120000) & 2 \\
\hline 3 & Higher income groups (>Rs. 120000) & 3 \\
\hline
\end{tabular}

Maximum possible score for annual income is $\mathbf{3}$

[The annual income groups were classified based on the classification of the Ministry of Rural Development, Government of India. Notification- June, 2011. Further, farmers who come under lower, medium or higher income groups were given a weightage of 1,2 and 3, respectively. Later, maximum weightage of 3 for the higher income group was considering as maximum possible score for the quantification of the annual income]

Score related to level of annual income groups

Annual Income Index (AII) = $\times 100$

Maximum possible score

\section{III.2 Annual expenditure}

It refers to the cumulative expenditure on various items such as food, clothing, house, health, education, rituals and marriages annually by the rehabilitant farmers. Weightages were assigned based on the expenditure classification of The National Sample Survey Office (NSSO), Ministry of Statistics and Programme Implementation. It is as indicated below.

\begin{tabular}{|l|l|l|}
\hline Sl. No. & Category & Weightages \\
\hline 1 & High expenditure (>Rs. 70000) & 1 \\
\hline 2 & Low expenditure (<Rs. 50000) & 2 \\
\hline 3 & Optimum expenditure (Rs. 50000 to 70000) & 3 \\
\hline
\end{tabular}

Maximum possible score for annual expenditure is $\mathbf{3}$

[The annual expenditure category was classified based on the classification of The National Sample Survey Office (NSSO), Ministry of Statistics and Programme Implementation, Government of India and Press release- $8^{\text {th }}$ July, 2011. Further, farmers who come under high, low and optimum expenditure categories were given a weightage of 1, 2 and 3 respectively. Therefore, maximum weightage of 3 for the optimum expenditure group was considered as maximum possible score for the quantification of the annual expenditure pattern]

Score related to level of annual expenditure

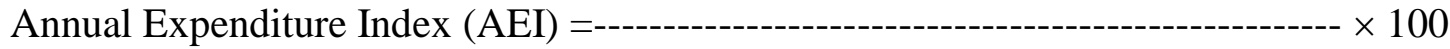

\section{III.3 Loan or credit}

Maximum possible score

It refers to total loans (debts) taken by the rehabilitant farmers from various sources like nationalized banks, co-operative societies etc., at the time of investigation. Weightages were assigned based on the scale of finance approved by the District Level Technical Committee. It is indicated as below. 


\begin{tabular}{|l|l|l|}
\hline Sl. No. & Loan or credit & Weightages \\
\hline 1 & <Rs. 49000 & 4 \\
\hline 2 & Rs. 49001 to 150000 & 3 \\
\hline 3 & Rs. 150001 to 390000 & 2 \\
\hline 4 & >Rs. 390000 & 1 \\
\hline
\end{tabular}

Maximum possible score for loan/credit is $\mathbf{4}$

[Loan/ credit pattern was classified based on Scale of finance approved by the District level Technical committee meet held on 25.11.2011 for the year 2012-2013. Further, who had taken less than Rs. 49000 loans was given highest weightage of 4 followed by 3, 2, 1 for Rs. 49001 to 150000 , Rs. 150001 to 390000 and >Rs. 390000, respectively. Therefore, maximum possible score of 4 was considered for quantification of loan/credit].

Score related to different category of loan/credit

Loan Pattern Index (LPI) = $\times 100$

\section{4. Repayment}

Maximum possible score

It refers to the regularity of the repayment of the loan/credit by the rehabilitant farmers. Weightage of 1 and 3 was assigned for defaulter and regular of the loan/credit for the quantification of the repayment. It is as indicated below.

\begin{tabular}{|l|c|l|}
\hline Sl. No. & Repayment & Weightages \\
\hline 1 & Defaulter & 1 \\
\hline 2 & Regular & 3 \\
\hline
\end{tabular}

Maximum possible score for repayment is $\mathbf{4}$

[The maximum possible score of 4 for repayment was obtained by combining defaulter and regular rehabilitant farmer's weightage (i.e. $1+3=4)$ ]

Score related to regular + defaulter of the loan/credit

Repayment Index $(\mathrm{RI})=$ $\times 100$

\section{III.5 Saving}

Maximum possible score

It refers to the total savings in rupees by the rehabilitant farmers in cash, gold or investment in LIC, mutual funds etc., at the time of survey. Weightage of 1, 2 and 3 were assigned for low, medium and high savings of the rehabilitant farmers, respectively. It is as indicated below.

\begin{tabular}{|l|l|l|}
\hline Sl. No. & Category & Weightages \\
\hline 1 & Low (up to $10 \%$ of the net income) & 1 \\
\hline 2 & Medium (11 to $25 \%$ of the net income) & 2 \\
\hline 3 & High (25 to $50 \%$ of the net income) & 3 \\
\hline
\end{tabular}

Maximum possible score for savings is $\mathbf{3}$

[The maximum weightage of 3 for higher savings group was considered as maximum possible score for the quantification of the savings]

Score related to level of savings

Savings Pattern Index (SPI) = $\times 100$ 
Maximum possible score

The maximum possible score for financial capital includes

\begin{tabular}{|c|l|c|l|}
\hline & Sub components & & Maximum score \\
\hline 1. & Annual income & $=$ & 3 \\
\hline 2. & Annual expenditure & $=$ & 3 \\
\hline 3. & Loan/credit & $=$ & 4 \\
\hline 4. & Repayment & $=$ & 4 \\
\hline 5. & Savings & $=$ & 3 \\
\hline & Total & $=$ & $\mathbf{1 7}$ \\
\hline
\end{tabular}

Therefore,

\section{Maximum possible score for financial capital is $\mathbf{1 7}$}

The financial capital index is the ratio of sum of the score of annual income + annual expenditure + loan/credit + repayment + savings to the maximum possible score of financial capital. The formula is as follows.

Score related to annual income + annual expenditure

$$
+ \text { loan/credit }+ \text { repayment }+ \text { savings }
$$

Financial Capital Index $(\mathrm{FCI})=$

Maximum possible score of financial capital

\section{HUMAN CAPITAL}

It is operationalised as the good health facilities, level of education, training exposure and awareness about developmental interventions, which are important for the successful pursuit of different livelihood options. Each sub component of human capital is measured by considering following sub-components and indicators as given below.

\begin{tabular}{|l|l|l|}
\hline SI.No. & Sub-components & Indicators \\
\hline IV.1 & Health facilities & Health facilities index (HFI) \\
\hline IV.2 & Education of the family head & Education of the family head index (EFHI) \\
\hline IV.3 & Training(s) exposure & Training index (TI) \\
\hline IV.4 & Awareness & Awareness index (AI) \\
\hline & Human capital & Human capital index (HCI) \\
\hline
\end{tabular}

\section{1. Health facilities}

It refers to the various medical facilities availability and their accessibility in terms of distance and means of transport in case of emergency situations. Following eleven items with weightages were considered based on the judges rating for quantification of health facilities available for the rehabilitant farmers. It is as indicated below.

\begin{tabular}{|l|l|l|}
\hline Sl. No. & Type of health facilities & Weightages \\
\hline A. & Frequency of visit to hospital & \\
\hline 1 & once in month & 1 \\
\hline 2 & once in quarter & 2 \\
\hline
\end{tabular}




\begin{tabular}{|l|l|l|}
\hline 3 & once in half year & 3 \\
\hline B. & Medical treatment available & \\
\hline 4 & Primary Health Centre & 3 \\
\hline 5 & Private clinic & 2 \\
\hline 6 & Traditional medical practitioner & 1 \\
\hline C. & Access to health facility & \\
\hline 7 & Less than $2 \mathrm{~km}$ & 3 \\
\hline 8 & 2 to $5 \mathrm{~km}$ & 2 \\
\hline 9 & More than $5 \mathrm{~km}$ of & 1 \\
\hline D. & $\begin{array}{l}\text { Means of transport in case of } \\
\text { emergency }\end{array}$ & \\
\hline 10 & Ambulance & 3 \\
\hline 11 & Bus/tempo/auto & 2 \\
\hline
\end{tabular}

Maximum possible score for health facilities is $\mathbf{1 6}$

[The maximum possible score of 16 for health facilities was obtained by combining maximum weightages allotted for each items (i.e. $3+5+3+5=16)$ ]

Score related to frequency of visit + medical treatment +

Health Facilities Index (HFI) $=$

$$
\text { access to health facility }+ \text { means of transport }
$$

\section{IV.2 Education of the family head}

Maximum possible score

It refers to the number of years of formal education acquired by rehabilitant family head at the time of investigation. Weightages were assigned for each item as follows.

\begin{tabular}{|l|l|l|}
\hline Sl. No. & Level of education & Weightages \\
\hline 1 & Illiterate & 1 \\
\hline 2 & Primary (up to $\left.5^{\text {th }}\right)$ & 2 \\
\hline 3 & Middle (up to $\left.10^{\text {th }}\right)$ & 3 \\
\hline 4 & Secondary (up to $\left.12^{\text {th }}\right)$ & 4 \\
\hline 5 & Collegiate $\left(>12^{\text {th }}\right)$ & 5 \\
\hline
\end{tabular}

Maximum possible score for education of the family head is $\mathbf{5}$

[The maximum weightage of 5 for education of the family head (i.e. collegiate $=>12^{\text {th }}$ year of schooling) was considered as maximum possible score for the quantification of the education of the family head]

Score related to education of the family head

Education of Family Head Index (EFHI) $\times 100$

IV.3 Training(s) exposure

Maximum possible score 
It refers to number and duration of the training undergone by the rehabilitant farmers during last three years. Weightages were assigned for each training subject based on the judges rating for quantification of training exposure. It is as indicated below.

\begin{tabular}{|l|l|l|}
\hline Sl. No. & Training subjects & Weightages \\
\hline 1 & Crop improvement & 3 \\
\hline 2 & Income Generating Activities (IGA) & 3 \\
\hline 3 & Vermi-compost production & 2 \\
\hline 4 & Nursery management & 2 \\
\hline
\end{tabular}

Maximum possible score for trainings exposure is $\mathbf{1 0}$

[The maximum possible score of 10 for training exposure was obtained by combining all the training subjects/items weightages (i.e. $3+3+2+2=10$ ). Because, farmers may receive all type of trainings mentioned above or either of one]

Score related to type of training subject

Trainings Index (TI) = ------------------------------------------------- $\times 100$

Maximum possible score

\section{IV.4 Awareness about developmental interventions}

It refers to the experience and awareness of the rehabilitant farmers about developmental interventions. Weightages for each developmental intervention were assigned based on the judges rating for quantification of the awareness about developmental interventions. It is as indicated below.

\begin{tabular}{|l|l|l|}
\hline Sl. No. & Type of developmental interventions & Weightages \\
\hline 1 & Crop production technologies & 1 \\
\hline 2 & Income Generating Activities (IGA) & 1 \\
\hline 3 & Livestock development activities & 1 \\
\hline 4 & Horticulture development schemes & 1 \\
\hline 5 & Agriculture department schemes & 1 \\
\hline
\end{tabular}

Maximum possible score for awareness about interventions is $\mathbf{5}$

[The maximum possible score of 5 for awareness about developmental interventions was obtained by summing all interventions weightages (i.e. $1+1+1+1+1=5)$ ]

Score related to types of interventions

Awareness Index (AI) = $\times 100$

Maximum possible score

The maximum possible score for human capital includes

\begin{tabular}{|c|l|l|l|}
\hline & Sub components & & Maximum scores \\
\hline 1. & Health facilities & $=$ & 16 \\
\hline 2. & Education of the family head & $=$ & 5 \\
\hline 3. & Trainings exposure & $=$ & 10 \\
\hline 4. & Awareness & $=$ & 5 \\
\hline & Total & $=$ & $\mathbf{3 6}$ \\
\hline
\end{tabular}

Therefore, 


\section{Maximum possible score of human capital is 36}

The human capital index is the ratio of score of health facilities + education of the family head + training exposure + awareness about the developmental interventions to the Maximum possible score of human capital multiplied with hundred. The formula is as given follows.

Score related to health facilities + education of the

$$
\text { family head + training exposure + awareness }
$$

Human Capital Index $(\mathrm{HCI})=$ $\times 100$

Maximum possible score of human capital

\section{V.SOCIAL CAPITAL}

Social capital is operationalised as the extent of organizational participation, participation in social activities, social status, occupation status and information accessibility of the rehabilitant farmers, which forms an effective social safety networks for improving livelihoods. Each sub components of social capital is measured by considering following sub-components and indicators as given below.

\begin{tabular}{|l|l|l|}
\hline Sl. No. & Sub components & Indicators \\
\hline V.1 & Organisation participation & Organisation participation index (OPI) \\
\hline V.2 & Social status & Social status index (SSI) \\
\hline V.3 & Occupational status & Occupational status index (OSI) \\
\hline V.4 & Participation in Social activities & Social participation index (SPI) \\
\hline V.5 & Information access & Information access index (IAI) \\
\hline & Social capital & Social capital index (SCI) \\
\hline
\end{tabular}

\section{1. Organizational participation}

It refers to the type and frequency of participation of the rehabilitant farmers in formal organization as regularly or occasionally. Following five types of formal organizations with weightages were considered for quantification of organizational participation. It is as indicated below.

\begin{tabular}{|l|l|l|}
\hline SI. No. & Types of organizations & Weightages \\
\hline A. & Gram Panchayat & \\
\hline & Regularly & 2 \\
\hline & Occasionally & 1 \\
\hline B. & Taluk Panchayat & \\
\hline & Regularly & 2 \\
\hline & Occasionally & 1 \\
\hline C. & Zilla Panchayat & \\
\hline & Regularly & 2 \\
\hline & Occasionally & 1 \\
\hline
\end{tabular}




\begin{tabular}{|l|l|l|}
\hline D. & Co-operative societies & \\
\hline & Regularly & 2 \\
\hline & Occasionally & 1 \\
\hline E. & Village Development Committee & \\
\hline & Regularly & 2 \\
\hline & Occasionally & 1 \\
\hline
\end{tabular}

Maximum possible score for organizational participation is $\mathbf{1 0}$

[The maximum possible score of 10 for organisational participation was obtained by multiplying the highest frequency of participation weightage with number of formal organizations (i.e. 2 x $5=10$ )].

Score related to type and frequency of organisational participation

Organization Participation Index $(\mathrm{OPI})=$ $\times 100$

\section{2. Social status}

Maximum possible score

It refers to the formal or non-formal position acquired by the rehabilitant farmer in the society for the purpose of public services. Following four types of positions with weightages were considered for quantification of social status. It is as indicated below.

\begin{tabular}{|l|l|l|}
\hline Sl. No. & Type of positions in the society & Weightages \\
\hline 1 & Opinion leader & 1 \\
\hline 2 & Progressive farmer & 2 \\
\hline 3 & Facilitator & 3 \\
\hline 4 & Elected member (GP/TP/ZP) & 3 \\
\hline
\end{tabular}

Maximum possible score for social status is $\mathbf{3}$

[The rehabilitant farmer may become opinion leader, progressive farmer, facilitator or elected member of GP/TP/ZP. Therefore, the highest position weightage of 3 for facilitator/elected member was considering for the quantification of the social status. If a farmer has more than one position like both progressive farmer and elected member then the highest weightage among positions was consider for the quantification. Because, the chance of having more than two positions in the study area was very low]

Score related to non-formal position

Social Status Index $($ SSI $)=$ $\times 100$

Maximum possible score

\section{V.3. Occupational status}

It refers to the rehabilitant farmer's occupation including wage earner, business man, service personnel, farming alone and farming + allied at the time of investigation to support livelihood. Following five types of occupations with weightages were considered for quantification of occupational status. It is indicated as below.
\begin{tabular}{|l|l|}
\hline Sl. No. & Type of occupation \\
\hline
\end{tabular}
Weightages 


\begin{tabular}{|l|l|l|}
\hline 1 & Wage earner & 1 \\
\hline 2 & Business man & 2 \\
\hline 3 & Service personnel & 3 \\
\hline 4 & Farming alone & 2 \\
\hline 5 & Farming + Allied & 3 \\
\hline
\end{tabular}

Maximum possible score for occupational status is $\mathbf{1 1}$

[The maximum possible score of 11 for occupation status was obtained by summing all types of occupation weightages (i.e. $1+2+3+3+3=11$ )]

Score related to types of occupation

Occupational Status Index $(\mathrm{OSI})=$ $\times 100$

\section{V.4 Participation in social activities}

\section{Maximum possible score}

It refers to the degree of participation of the rehabilitant farmer in non-formal activities. Following six non-formal activities with weightages were considered based on the judges rating for quantification of participation in social activities. It is as indicated below.

\begin{tabular}{|l|l|l|}
\hline Sl. No. & Type of participation in social activities & Weightages \\
\hline 1 & Village festivals & 1 \\
\hline 2 & Conflict resolution & 1 \\
\hline 3 & School programmes & 2 \\
\hline 4 & Recreational activities like fairs, films, drama, rituals etc & 2 \\
\hline 5 & Infrastructure development of village & 3 \\
\hline 6 & $\begin{array}{l}\text { Helping the villagers in getting the subsidies/Govt. } \\
\text { Facilities }\end{array}$ & 3 \\
\hline
\end{tabular}

Maximum possible score for participation in social activities is $\mathbf{1 2}$

[The maximum possible score of 12 for participation in social activities was obtained by combining all types of social activities weightages (i.e. $1+1+2+2+3+3=12$ ). Because, farmer may participate in all the social activities mentioned above or either of one]

Score related to degree of social participation

Social Participation Index (SPI) = $\times 100$

\section{5. Information access}

Maximum possible score

It refers to the extent of access to information by the rehabilitant farmers from different categories of people and experts. Following six source of information with weightages were considered for quantification of information access. It is as indicated below.

\begin{tabular}{|l|l|l|}
\hline Sl. No. & Source of information & Weightages \\
\hline A. & General & \\
\hline & Family members & 1 \\
\hline & Neighbors/friends & 2 \\
\hline & Opinion leader & 3 \\
\hline
\end{tabular}




\begin{tabular}{|l|c|l|}
\hline & Elected member of GP/TP/ZP & 3 \\
\hline B. & Agriculture & \\
\hline & Department (AAO/AO/ADA) & 2 \\
\hline & University scientist/KVK & 3 \\
\hline
\end{tabular}

Maximum possible score for information access is $\mathbf{1 4}$

[The maximum possible score of 14 for information access was obtained by combining all sources of information weightages $(1+2+3+3+3+2=14)$. Because, farmer may access information from all the sources mentioned above or either of one]

Score related to different source of information

Information Access Index (IAI) = $\times 100$

Maximum possible score

The maximum possible weightage for social capital includes

\begin{tabular}{|c|l|c|l|}
\hline & Sub components & & Maximum score \\
\hline 1. & Organisation participation & $=$ & 10 \\
\hline 2. & Social status & $=$ & 3 \\
\hline 3. & Occupational status & $=$ & 11 \\
\hline 4. & Participation in Social activities & $=$ & 12 \\
\hline 5. & Information access & $=$ & 14 \\
\hline & Total & $=$ & $\mathbf{5 0}$ \\
\hline
\end{tabular}

Therefore,

Maximum possible score for social capital is $\mathbf{5 0}$

social capital index is the ratio of score of organisation participation + social status + occupation status + social participation + information access to the maximum possible score of social capital multiplied by hundred. The formula is as follows.

Score related to organisation participation + social status + occupation status + social participation + information access

Social Capital Index $(\mathrm{SCI})=$

Maximum possible score of social capital

Score for Livelihood security

\begin{tabular}{|l|l|l|l|}
\hline & Components & & Maximum score \\
\hline 1 & Natural capital & $=$ & 214 \\
\hline 2 & Physical capital & $=$ & 39 \\
\hline 3 & Financial capital & $=$ & 17 \\
\hline 4 & Human capital & $=$ & 36 \\
\hline 5 & Social capital & $=$ & 50 \\
\hline & Total & $=$ & $\mathbf{3 5 6}$ \\
\hline
\end{tabular}


Therefore,

Maximum possible score for Livelihood security is 356

The Livelihood security index is the ratio of score of natural capital + physical capital + financial capital + human capital + social capital to the maximum possible score of Livelihood security multiplied with hundred. The formula is as follows.

\begin{tabular}{|c|c|}
\hline & $\begin{array}{l}\text { Score related to natural capital + physical capital + } \\
\text { financial capital + human capital + social capital }\end{array}$ \\
\hline & Maximum possible score for Livelihood security \\
\hline
\end{tabular}

\section{RESULT AND DISCUSSION:}

After development of the Livelihood Security index (LSI), the livelihood security of the rehabilitant farmers was measured by using same formula.

\section{Livelihood Security of the rehabilitant farmers}

The results in Table 1 depicted that Livelihood Security of the rehabilitant farmers was found to be 54.66 percent. The rehabilitant farmers possessed relatively higher physical capital and financial capital, due to the compensation money provided by the Government for their submerged land and all most all rehabilitant farmers availed benefit of House Construction Grants (HCG) but, rehabilitant farmers natural capital was found to be low because, they were shifted to new area in the year 2005 onwards. During this short span of time they were unable to establish natural capital like irrigation infrastructure, development of the land, vegetation, livestock composition, cropping system and farming system. During data collection it was learnt that, rehabilitant farmers still had strong attachment with their earlier place, so they faced difficulty to adjust with the new place.

Table 1: Livelihood Security of the rehabilitant farmers

\begin{tabular}{|l|l|l|}
\hline Sl. No. & Components & $\begin{array}{l}\text { Livelihood Security Index } \\
(\mathbf{\%})\end{array}$ \\
\hline 1 & Natural capital & 48.77 \\
\hline 2 & Physical capital & 72.05 \\
\hline 3 & Financial capital & 68.28 \\
\hline 4 & Human capital & 63.59 \\
\hline 5 & Social capital & 55.24 \\
\hline & Livelihood Security & $\mathbf{5 4 . 6 6}$ \\
\hline
\end{tabular}




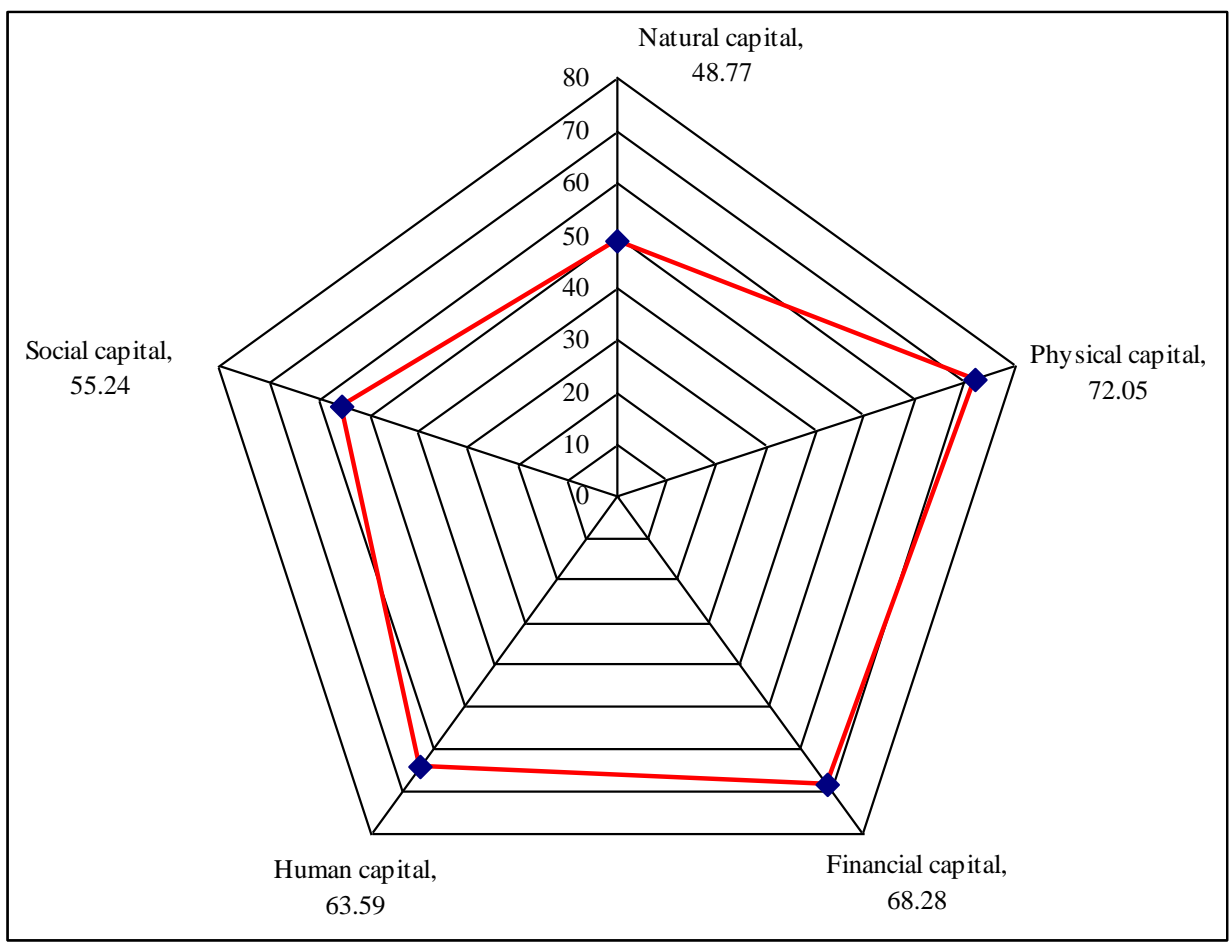

Fig. 1:

\section{Livelihood security of the rehabilitant farmers}

Among the components of Livelihood Security (Fig.1), natural capital was observed low (48.77\%). Human capital (63.59\%) and social capital (55.24\%) performed moderately among all the capitals. However, physical capital (72.05\%) and financial capital (68.28\%) performed better among the capitals/components of the Livelihood Security. The results discussed about the natural, physical, financial, human and social capital anywhere in this chapter holds good here also.

Natural capital of the rehabilitant farmers was found to be the lowest among all the capitals. Therefore, Government could modify the amount reserved under Land Purchase Grants (LPG) time to time based on the existing land value for the purchase of new land.

Social capital performed moderately among the components of the Livelihood Security. Therefore, social capital could be enhanced by providing proper counseling for rehabilitant farmers to overcome stress and shocks due to the rehabilitation process and take due care to formation of new SHG, youth clubs and farmers hub.

Human capital performed moderately among the capitals. Hence, NGO and related institutions could create awareness about the Income Generating Schemes (IGS), take due care about the rehabilitant farmers residing far away from the DHQ while selection of candidates for training programmes and also take feedback from all the beneficiaries of the training programmes. Guidance should be provided through the follow up work.

Physical capital performed better among the capitals. However, farm implements and farm machineries performed inadequately among the subcomponents of the physical capital. Therefore, Government could make a provision to establish Farm Implements and Machineries 
Centre unit (FIMC) at each of the Rehabilitation Centres (RC) and hire them at reasonable rate. Due to this, the problem of labour and inadequate availability of the farm implements and machineries at the time of agriculture operation will be reduced.

Financial capital performed better among the capitals. However, savings was observed low among the subcomponents of the financial capital. Therefore, an attempt could be made to formulation of more number of SHGs and link them to Agricultural Technology Management Agency (ATMA) and financial institutions.

\section{CONCLUSION:}

The developed Livelihood Security Index (LSI) will help to measure the Livelihood security of the Rehabilitant farmer's interms of Livelihood Capitals possession i.e. Natural, Physical, Financial, Human and Social capitals. The developed methodology enable the researchers, academicians and policy makers to assess the Livelihood Security of any Project Displaced farm Families (PDF) due to displacement by corporate companies (Steel, Mining, Nuclear power etc) National Highway, Special Economic Zone (SEZ) and also due to natural calamities like drought, flood, earth quick, etc., if it is proved to be reliable in new conditions.

\section{REFERENCES:}

Uday Kumara, E. P. N. and Shrestha, R. P.. 2011. Assessing livelihood for improvement: Samanalawewa reservoir environs, Sri Lanka, Intl. J. Sust. Dev. World Ecol., 18 (4): 366-376.

Nesar, A, MaxTroell, Edward, H. A., James, and F. M. 2010. Prawn post larvae fishing in coastal Bangladesh: Challenges for sustainable livelihoods. Marine Policy., 34: 218-227.

Tanvir, A., Munir, A, Babar, S. and Abid, S. 2007b. Impact of participatory forest management on vulnerability and livelihood assets of forest-dependent communities in northern Pakistan, Intl. J. Sust. Dev. World Ecol., 14 (2) : 211- 223.

Lindenberg, M. 2002. Measuring Household Livelihood Security at the Family and Community Level in the Developing World. World Development, 30 (2): 301-318.

Swaminathan, M. S. 1991. From Stockholm to Rio de Janeiro: The Road to Sustainable Agriculture, Monograph No. 4, M. S. Swaminathan Research Foundation, Chennai, India. 